\title{
DIE HART VAN VERPLEGING
}

\author{
“Help my om die norme van my beroep te verstaan en te gehoorsaam en om die regte, simpatieke \\ gesagsleiding te gee ...",
}

\section{WILMA KOTZÉ}

D ie wêreld van die mens het grense. Elke landskap het grense. Dit is juis die begrensdheid daarvan wat dit afbaken, spesifiek maak, binne die gesigsveld en waarnemingsvermoëns van die mens plaas, sodat hy dit kan leer ken en begryp. Dit is dus die grense wat die wêreld kenbaar en interpreteerbaar, daarom veiliger maak, en aan die mens die moontlikheid bied om perspektief te kry.

Die lewe van die mens verloop in terme van tyd. Die tye van die week en die jaar vertoon met reëlmaat dié grense wat die wisseling en verskeidenheid van dag en nag en die seisoene bring en daarmee telkens die geleentheid vir vernuwing en hoop.

In gemeenskapsverband leef die mens binne die veilige grense van die norme - van wetgewing, godsdienstige voorskrifte, professionele gedragskodes en die verinnerliking daarvan tot eie lewensbeskouing. Om getrou aan die gesag van hierdie norme te leef, word as voorwaarde vir ordelike sinvolle menslike bestaan beskou. Die hoogste opgawe in die lewe van elke mens is daàrom om die wese en doel van die norme te leer ken en verstaan as onontbeerlik om waarlik tot betekenisvolle bestaan te kom - en om hierdie lewenswaarheid uit te leef en ywerig en reg te vertolk aan diegene wat van sy/haar leiding afhanklik is. Nou is die grootste genade van menswees die werklikheid dat die mens gebore word met die moontlikheid en daarom die opdrag om verantwoordelik te wees: om tussen goed en kwaad te onderskei, om binne en deur die grense wat daar vir hom gestel word betekenisvol te leef.

Ook die verpleegkundige staan onder die opgaaf om tot ontplooiing van haar persoonlikheid en beroepsvaardighede tot sinvolle persoonlike lewe en beroepsbeoefening binne en deur die grense van gemeenskaps-, godsdienstige en professionele norme te kom. Dit is slegs moontlik in dié mate dat hierdie norme vir haar persoonlik betekenisvol en deel van haar eie lewensbeskouing word. Die mens is egter feilbaar. Om te leer om meer sinvol te leef en werk moet 'n voortdurende, daaglikse strewe wees.

Die norme van verpleegkundige praktyk waarbinne en waardeur die verpleegkundige funksioneer bied nie net beperkinge nie, maar ook moontlikhede. Dit bied die riglyne vir veilige verpleging. Die vertrekpunt en sentrale oorweging van al die norme waarmee die verpleegkundige haar moet identifiseer, is eerbied vir die mens as waardigheid en moontlikheid.
Die hoofelement van haar ekspressiewe taak is om, vanuit haar eie gehoorsaamheid aan die gesag van die norme, die pasiënt, namate dit nodig is, te lei tot begryping en gehoorsaming van daardie maatreëls wat dit vir hom moontlik sal maak om tot hernude sinvolle bestaan te kom.

Dit is só dat die element van gesag as simpatieke gesagsleiding onmisbaar in alle hulpverleningsituasies is. Daarsonder is geen begeleiding tot meer verantwoordelike bestaan moontlik nie. Daar is in die verpleegkunde geen plek vir die afdwing van gesag nie, maar wel vir begeleiding tot gehoorsaamheid aan gesag - die gesag van dit wat behoort te wees, die gesag van die norme. Hierdie gesag - as gesagsleiding, vorm saam met begryping en vertroue die bestanddele vir die groei van 'n belewing van veiligheid, van geborgenheidsof terapeutiese omgewing waarbinne die verplegingsgebeure sinvol voltrek kan word.

Die verpleegkundige wat die gesag van die norme erken en gehoorsaam, kan dit betekenisvol vertolk aan diegene wat van haar leiding afhanklik is. Haar gesag berus

* enersyds, op haar begryping en aanvaarding van die sieke as mens wat oor die moontlikheid, en as waardigheid oor die reg beskik om, selfs op sy sterfbed, tot sinvervulling te kom, en

* andersyds, op haar besondere beroepskundigheid en haar erkenning van die noodsaaklikheid dat die wetenskap slegs in diens van die mens beoefen moet word en nie as doel op sigself nie.

'n Gesagsverhouding word eers moontlik wanneer daar wedersyds tussen verpleegkundige en pasiënt erkenning en aanvaarding van mekáár se gesag plaasvind. Dit gebeur pas wanneer die oortuiging by die pasiënt posvat dat die verpleegkundige hom in sy menslike moontlikheid en waardigheid raaksien, hy haar leer vertrou vanweë haar professionele kundigheid en vaardigheid, en wanneer hy begryp dat sy handel in ooreenstemming met die norme waartoe sy professioneel verbind is. Op haar beurt maak sy haar leiding vir die pasiënt aanvaarbaar wanneer sy hom erken as verantwoordelike persoon deur op sý mening ag te slaan, sý kennis te benut, hóm telkens te raadpleeg en deel te laat word van die terapeutiese gebeure.

Gesagsleiding word aangepas by die lewensfase van die pasiënt. Die kind, moet onthou word, is reeds 'n persoon wat aanspraak maak op erkenning van 'n eie identiteit. Nogtans is hy altyd aangewese op die liefdevolle 
nabyheid van 'n kundige en bereidwillige volwassene. $\mathrm{Hy}$ het die sekerheid van simpatieke gesagsleiding nodig. Hy wil hê dat daar grense aan hom gestel word omdat dit sy veiligheid waarborg. Om aan homself, sy eie keuses en besluite oorgelaat te word, beteken om in sy nie-weet-hoe-nie aan onsekerheid en onveiligheid uitgelewer te word.

Die volwassene is iemand wat selfbepalend optree, wat vanuit 'n eie gevestigde rangorde van waardevoorkeure kies en beslis. $\mathrm{Hy}$ is iemand wat verantwoorelikheid kan aanvaar en bereid is om die gevolge daarvan te verantwoord. In sy onmag en onkunde om homself te handhaaf en sy siekwees en tydens die herwinning van sy gesondheid, is hy ten dele afhanklike en het ook hy behoefte aan simpatieke gesagsleiding. Sy moontlikhede ten spyt is hy intens bewus van sy feilbaarheid. In sy pogings om weer eens heer en meester van sy eie lewe te word, mag hy telkens faal. Nogtans is daar by hom die verwagting dat sy mislukkinge in vertroue bewaar sal word. Wanneer hy in sy verhouding met die verpleegkundige die blyke ondervind dat sy hom steeds vertrou en vir hom geheimhouding verseker, ontplooi sy dankbaarheid jeens haar tot groter gehoorsaamheid aan haar gesag.

Ook die bejaarde sieke wil eerbiedig word as mens wat tot eie besluite bereid en in staat is. Soos elke ander sieke hunker ook hý na geborgenheid en is ook hy gesagsbehoewend. Nou gebeur dit dikwels dat die verpleegkundige veel jonger as hierdie persoon is. Haar taak om die bejaarde pasiënt tot aanvaarding van haar gesag te lei verg dikwels baie tyd, baie geduld en baie liefde. Volharding is van deurslaggewende belang. Geen persoon, geen sieke, is egter werklik bestand teen die volgehoue blyke van aanvaarding deur die betoning van eerbied en liefdevolle versorging nie.

Gesagsleiding vra van die verpleegkundige om die pasiënt op te roep tot die aanvaarding van verantwoordelikheid. Dit is soms nodig om die handelinge en gesindheid van 'n pasiènt af te keur. In oomblikke van mislukking, wanner die moed kwyn, is daar die nood van 'n meelewende verpleegkundige wat sy swakheid sal eerbiedig, maar steeds vertroue in hom sal behou en dit sal toon. Só 'n belewing van geborgenheid maak dit vir die sieke soveel makliker om haar leiding te aanvaar en opnuut te volhard.

Die pasiënt, veral die ernstig-sieke, het die onderskraging en hulp - die begeleiding van 'n kundige medemens nodig om tot verwerking van sy siekwees te kom en betekenis, sin, daarin en daardeur te vind. Toenemende aanvaarding, die groei tot geestelike triomfering oor die kwynende liggaamlikheid, is altyd tydsaam. 'Haas jou langsaam' is 'n sleutelbegrip. Selfs die geringste vordering moet die verpleegkundige raaksien, goedkeur, aanprys. Oorhaastigheid en onrealistiese eise is hoogs onwenslik, veral by die kind, die swaar-sieke en bejaarde, omdat dit hulpeloosheid beklemtoon en die vermoede bring dat daar tóg nie begrip, vertroue en aanvaarding is nie.

Regverdigheid, oordeelkundigheid, liefde en meelewing is in gesagsleiding onontbeerlik. Die sieke wil as gesagsgenoot, as persoon met ervaring en kennis in eie reg raakgesien en erken word, selfs al is hy maar 'n kind! Die sieke wil geraadpleeg word, hy wil sy mening gee, hy wil deelgenoot in alle beplanning en in elke verkenning van sy siekwees en sy terapie word. Wanneer hy só raakgesien en in die terapeutiese gebeure aanvaar word, word sy situasie vir hom weer eens leefbaar en skep hy moed om die toekoms aan te durf.

Die moontlikhede wat gehoorsaming van die norme bied - juis omdat dit grens skep waarbinne die verplegingsgebeure veilig voltrek kan word, grense waarbinne die sieke meer verantwoordelik en meer sinvol kan leef, selfs al sou dit 'n nuwe, anderse lewenswyse vir die toekoms beteken - gee aan die begrip 'gesag' die positiewe betekenis van skeppende arbeid.

Simpatieke gesagsleiding dra by tot begryping en vertroue om veiligheidsbelewing by beide die verpleegkundige en die pasiënt te laat ontluik. Dit dra ook by tot die ontplooiing van die persoonlikheid omdat dit beide die verpleegkundige en die pasiënt dwing tot besinning, tot nederigheid, maar ook hul blik verhef om hul eie moontlikhede raak te sien. Gehoorsaamheid aan die gesag van die norme herberg die kiem vir ordelike, verantwoordelike lewenswyse - vir sinvervullende bestaan en sinvervullende beroepsarbeid. 